\title{
Putative spawner-isolated mortality virus associated with mid-crop mortality syndrome in farmed Penaeus monodon from northern Australia
}

\author{
Leigh Owens ${ }^{1, *}$, Gholamreza Haqshenas, Catriona McElnea, Robert Coelen \\ Department of Microbiology and Immunology, Australian Institute of Tropical Veterinary and Animal Sciences, \\ James Cook University, Townsville, Queensland 4811, Australia
}

\begin{abstract}
Beginning in 1994, farms in northern Australia experienced a higher than normal mortality rate in 12 to $15 \mathrm{~g}$ prawns from growout ponds. The farmers named this problem mid-crop mortality syndrome (MCMS). Intramuscular injection of filtered $(450 \mathrm{~nm})$, cell-free extracts of moribund prawns from these ponds killed healthy prawns between 5 to $30 \mathrm{~d}$ post-injection. A $20 \mathrm{~nm}$ virus was visualized by electron microscopy from a $1.4 \mathrm{~g} \mathrm{ml}^{-1}$ band recovered from caesium chloride gradients of extracts from the moribund prawns. DNA was extracted from this band, restriction enzyme digested and ligated into pGEM7zf(+) vector. A digoxigenin-labelled polymerase chain reaction (PCR)generated, gene probe was subsequently prepared by amplifying an inserted sequence (approximately $2 \mathrm{~kb}$ ) of one selected clone specific for the virus. Specimens of the moribund prawns stained positively by in situ DNA hybridization in endodermal tissues, including the apical ends of hepatopancreatic tubules, the midgut and hindgut caecae, the midgut, and the hindgut folds. In prawns that showed haemocytic enteritis, some haemocytes in the affected midgut showed limited staining. The positivelystaining cells showed no cytolysis. In prawns injected with cell-free viral extracts, additional tissues were positive by probe analysis, including strong staining in the male reproductive tract, specifically in the terminal ampoule and the medial vas deferens. Limited staining also occurred in the ovary and in both the stromal matrix and spheroid cells of the lymphoid organ. It was evident that the infection was enteric by natural pathways and systemic by injection. Historical specimens of Penaeus monodon experimentally infected with spawner-isolated mortality virus (SMV) were probe-positive in exactly the same pattern as the naturally and experimental MCMS prawns. Altogether, the evidence suggested that the MCMS agent was a parvo-like virus very similar or identical to SMV
\end{abstract}

KEY WORDS: Penaeus monodon - Mid-crop mortality syndrome - Spawner-isolated mortality virus Parvovirus

\section{INTRODUCTION}

Prior to 1994, the culture of Penaeus monodon on farms in northern Australia was characterised by good yields and appeared free of the massive mortalities observed elsewhere in the Indo-Pacific region. However, 4 farms stocked in January 1994 began to experience a higher than normal rate of mortality in 12 to $15 \mathrm{~g}$ prawns from their grow-out ponds. The mortalities reached as high as $80 \%$ in some ponds and there

•E-mail: leigh.owens@jcu.edu.au was some evidence that 3 of the farms had been supplied with postlarvae from the same hatchery. The farmers referred to this problem as mid-crop mortality syndrome (MCMS). Due to commercial concerns and the consequent lack of dialogue, the aquaculture industry and government failed to recognize that it was facing a major industry-wide epizootic until early 1995. Thus, coordinated disease investigations did not start until mid 1995, whereby 18 mo of response time were lost. The syndrome produced no histopathognomic lesions and this greatly hampered investigation. Early investigations showed that filtered, cell-free extracts could kill clinically healthy prawns 
between 7 to $20 \mathrm{~d}$ post-exposure (Muir, Owens \& Anderson unpubl.). Two distinct viral types were observed by electron microscopy in moribund prawns and observations on virogenesis suggested that at least 3 viruses might be involved. This report describes investigations into one of the virus-like particles associated with MCMS

\section{MATERIALS AND METHODS}

Bioassays. Penaeus monodon, Penaeus esculentus, Penaeus japonicus, Penaeus merguiensis and Metapenaeus ensis ( 3 to $10 \mathrm{~g}$ ) were caught by cast net in the grow-out ponds of a number of farms and research institutes in northern Australia. Before stocking of shrimp, all tanks and equipment were disinfected for $24 \mathrm{~h}$ with a saturated solution of calcium hypochlorite, rinsed twice with tap water, and filled with sea water. The $180 \mathrm{l}$ experimental tanks were equipped with 2 corner filters and 2 air stones and stocked with 10 prawns in each nonreplicated, treatment group. The water temperature was maintained at 21 to $26^{\circ} \mathrm{C}$ and the salinity at 25 to 37 ppt. The filter wool was changed weekly. Uneaten food, moults, and faecal strings were removed from the tanks daily.

Prawn extracts were prepared from $25 \mathrm{~g}$ of frozen cephalothoraxes from both diseased and healthy prawns. The tissue was homogenised in $25 \mathrm{ml}$ of Dulbecco's Modified Eagle's Medium (DMEM, Trace Bioscience PL, cat. no. 50-013-PB) with $1 \%$ calf serum, in stomacher bags. The homogenate was made up to $100 \mathrm{ml}$, frozen and stored overnight at $-20^{\circ} \mathrm{C}$. After thawing, the homogenate was clarified by centrifugation at $9000 \times g$ in an Eppendorf microfuge for 15 min. The extract was filtered through a $450 \mathrm{~nm}$ Sartorius Minisart filter using a $2.5 \mathrm{ml}$ Terumo disposable syringe to form the cell-free extract. The fitrate was plated on a blood agar plate and a marine agar plate to ensure sterility. Only once was bacterial contamination observed, so the filtrate was passed through a $220 \mathrm{~nm}$ Sartorius Minisart filter and replated. Prawns to be used in the bioassay were intramuscularly inoculated with an extract from other members of their cohort as a test of latent viruses. This group was called the true controls; those recieving only DMEM were called controls, and those intramuscularly inoculated with 20 to $50 \mu \mathrm{l}$ of moribund prawn extract were the test animals. Any mortalities within $24 \mathrm{~h}$ from the time of inoculation were considered to result from toxic protein shock and were replaced. The survival curves were analysed using the Life Tables in SPSS ${ }^{M}$ software.

Viral isolation. Prawns were collected from farms reporting mortality events and frozen at $-20^{\circ} \mathrm{C}$. The frozen cephalothoraxes and gut tissues were homo- genised in a Waring laboratory blender, at a concentration of 10 heads per $200 \mathrm{ml}$ of cold TNE buffer (50 mM Tris-HCl pH 7.4, $10 \mathrm{mM} \mathrm{NaCl}, 1 \mathrm{mM}$ EDTA) (Bonami et al. 1990) and the homogenates were kept on ice. The homogenate was frozen, thawed and stepclarified by centrifugation at $4^{\circ} \mathrm{C}$ and 6000,12000 and $28000 \times g$ in a Beckman J2-21 centrifuge using a JA17 rotor for 10,15 and $30 \mathrm{~min}$, respectively. The final supernatant extract was pelleted by ultracentrifugation at $240000 \times g$ for $3 \mathrm{~h}$ at $4^{\circ} \mathrm{C}$ in a Beckman L 7-55 ultracentrifuge, and the pellet was resuspended in a small volume of TN buffer $\left(20 \mathrm{mM}\right.$ Tris- $\mathrm{HCl}_{1} 400 \mathrm{mM}$ $\mathrm{NaCl}$ at $\mathrm{pH}$ 7.5) (Bonami et al. 1990). This suspension was then centrifuged on a 25 to $45 \%$ caesium chloride ( $\mathrm{CsCl}$ ) gradient at $210000 \times g$ for $16 \mathrm{~h}$ at $4^{\circ} \mathrm{C}$ after which bands were localized by transmitted light. The refractive index of the bands was measured on an Atago refractometer and converted to buoyant density.

Electron microscopy. Bands of interest were repelleted as described above. The pellets were drained of supernatant and resuspended in a few drops of TNE. A small drop of these suspensions was placed on Parafilm and a formvar-coated $(0.6 \%)$ electron microscopic grid placed on top. After 2 to 3 min, the grid was removed and allowed to dry. After rinsing with a drop of TN buffer, it was put onto a drop of uranyl acetate $(2 \%)$ negative stain for another $2 \mathrm{~min}$, removed and allowed to dry. It was then examined at $80 \mathrm{kV}$ in a Jeol 2000 FX transmission electron microscope (TEM).

DNA probe. DNA was extracted from the $\mathrm{CsCl}$ purified virus using $1 \%$ sodium dodecyl sulphate and $100 \mu \mathrm{g} \mathrm{m}^{-1}$ proteinase $\mathrm{K}$ as described by Sambrook et al. (1989). The ssDNA was then complemented with Klenow polymerase (O'Shade et al. 1986). The resulting dsDNA was then ligated to EcoR1 adapters and subsequently digested with BamH1. Finally it was ligated into pGEM7zf(+) which had been doubly digested with EcoR1 and BamH1. The vector was used to transform competent Escherichia coli strain JM109. Those clones containing large inserts were selected by electrophoresis following EcoRI and BamHI plasmid digestion. Inserts containing prawn DNA were eliminated using dot-blot hybridisation against Penaeus monodon DNA. Chosen clones were partially sequenced and compared with GenBank sequences using a Blastn search (Altschul et al. 1990) to determine those most likely to contain viral DNA. The final selected probe was labelled with DIG-11-dUTP (Boehringer Mannheim) using the polymerase chain reaction (PCR) and M13 primers whose complementary sequences were incorporated into the vector The reaction cocktail included $150 \mu \mathrm{M}$ dNTP (30 $\mu \mathrm{M}$ DIG-11-dUTP and $120 \mu \mathrm{M}$ dTTP), $0.5 \mu \mathrm{M}$ primers, $2.5 \mathrm{mM} \mathrm{MgCl}_{2}$ and $1 \mathrm{U}$ of $T$ th polymerase (Biotech International Ltd) in a reaction volume of $50 \mu \mathrm{l}$. After initial heating of the reaction 
mixture at $95^{\circ} \mathrm{C}$ for $4 \mathrm{~min}, 35 \mathrm{PCR}$ cycles were carried out with denaturation at $95^{\circ} \mathrm{C}(50 \mathrm{~s})$, annealing at $55^{\circ} \mathrm{C}$ $(50 \mathrm{~s})$ and extension at $72^{\circ} \mathrm{C}$ ( $2 \mathrm{~min}$ ) and with a final extension time of $7 \mathrm{~min}$. Purity of the PCR product was determined by $1 \%$ agarose gel electophoresis of an aliquot. Unincorporated digoxigenin (DIG-dUTP) was separated from the labeled product using ultrafiltration with a Centricon 100 (Amicon) membrane and the concentration of probe was estimated by comparison with a labeled standard (Boehringer Mannheim) following the protocol provided by the manufacturer.

Processing of specimens for histological analysis. Prawns were fixed in Davidson's fixative by injection and immersion for $24 \mathrm{~h}$ after which they were transferred to $70 \%$ ethanol for subsequent storage (Bell \& Lightner 1988). They were subsequently processed and embedded as described by Culling et al. (1985). Sections of $5 \mu \mathrm{m}$ were cut and adhered to silane(Sigma Chemical Co.) treated glass slides and left overnight at $60^{\circ} \mathrm{C}$. In addition to these specimens, similarly embedded, stored tissues from Penaeus monodon experimentally infected with spawner-isolated mortality virus (SMV; Fraser \& Owens 1996) were sectioned and analyzed for comparison.

Hybridisation. The in situ hybridistion method used was based on that described by Rolighed \& Lindeberg (1996) with some modifications. Briefly, tissue sections were deparaffinised through xylene, washed several times in ethanol and rehydrated in distilled water before final equilibration in TNE buffer. Tissues were then made permeable to probe by digestion with proteinase $\mathrm{K} 100 \mu \mathrm{g} \mathrm{ml} \mathrm{m}^{-1}$ at 37 to $56^{\circ} \mathrm{C}$ for $10 \mathrm{~min}$. Digestion was stopped by addition of glycine to a final concentration of $0.2 \%$ weight/volume $(\mathrm{w} / \mathrm{v})$. Tissues were then stablised in $0.4 \%$ paraformaldehyde for $5 \mathrm{~min}$ at $4^{\circ} \mathrm{C}$. This was followed by 2 washes in double distilled water for 5 min after which tissues were air dried for $5 \mathrm{~min}$. Probe was then applied at a concentration of $1 \mathrm{ng} \mu^{-1}$ in hybridisation buffer (50\% formamide, $5 \%$ dextran sulphate, $0.5 \mathrm{mg} \mathrm{ml}^{-1}$ sperm DNA, Denhardt's solution, $4 \times$ saline sodium citrate (SSC), (0.15 M NaCl and $0.015 \mathrm{M}$ sodium citrate at $\mathrm{pH}$ 7.0) followed by placement of a coverslip and simultaneous probe and target DNA denaturation at $95^{\circ} \mathrm{C}$ for $8 \mathrm{~min}$. Then, slides were immediately quenched on ice for $1 \mathrm{~min}$ and hybridised at $37^{\circ} \mathrm{C}$ overnight. Nonspecifically bound probe was removed by washing in $2 \times \mathrm{SSC}$ twice for $5 \mathrm{~min}$ at room temperature and once in $0.1 \times \mathrm{SSC}$ at $37^{\circ} \mathrm{C}$. Detection of bound probe was carried out according to the protocol described by Durand et al. (1996) with colour development carried out overnight. Tissues were counterstained with $0.5 \%$ aqueous Bismarck Brown for $30 \mathrm{~s}$ and mounted with Crestia (Scientific Supplies) and Depex (Gurr).

\section{RESULTS}

\section{Bioassays}

Thirty-two batches of prawns from 6 farms and 2 research institutes were tested from 1995 to 1997 Statistically $(p<0.01)$, all the controls and true controls from 1995 and 1997 were identical with high survival rates $(\sim 100 \%)$. All the test animals, the controls of 1996 and true controls of 1996 died at a rapid rate with rarely any survivors at the end of a $30 \mathrm{~d}$ trial. Late in 1996, there appeared to be 2 types of mortality within 1 source of inoculum: $25 \%$ of prawns died within 5 to $10 \mathrm{~d}$; the remainder died between 15 and $30 \mathrm{~d}$. Mortality was bimodal with one mode on Day 8 and the other on Day 15. In bioassays, all the species of prawns tested (Penaeus monodon, P. esculentus, $P$. japonicus and $P$. merguiensis) died at identical rates except for Metapenaeus ensis, which survived twice as long as the other species. If the source of the inoculum was from reproductively mature prawns, the mortality was slower than if the inoculum was from juvenile prawns.

\section{Viral isolation and characterisation}

A number of light diffracting bands was seen after isopycnic centrifugation through caesium chloride of extracts from moribund prawns. One of the bands that appeared more commonly had a buoyant density of $1.4 \mathrm{~g} \mathrm{ml}^{-1}$. Transmission electron microscopy of a negatively stained aliquot revealed particles of approximately 20 to $25 \mathrm{~nm}$ in diameter (Fig. 1).

\section{In situ hybridisation}

Digoxigenin-labelled probes were used for in situ hybridisation studies using histological tissue sections collected from suspected outbreaks of MCMS over several years. Prawns from farms showed blue/black precipitation in endodermal tissues with the most intense staining in the nuclei. Some cells gave staining only in the nucleoli. The cells of the apical end of the hepatopancreatic tubules (Fig. 2), the midgut caecae (Fig. 3), the midgut (Fig. 4), the hindgut caecae, and the hindgut folds all gave positive reactions. In prawns showing haemocytic enteritis, some haemocytes in the affected midguts showed limited staining. The infected cells showed no cytolysis. However, in prawns injected with cell-free extract from moribund MCMS prawns, additional tissues were positive on probe analysis. Of these, the most intensely stained were those tissues of the male 
reproductive tract at the terminal ampoule (Fig. 5) and the medial vas deferens. Limited staining occurred in the ovary (Fig. 6) and in both the stromal matrix and spheroid cells of the lymphoid organ (Fig. 7). Occasionally, some cells of the haematopoietic tissue had traces of staining. It appeared that infection was enteric by natural pathways and systemic by injection. Moribund prawns collected from one farm in March 1995, from a different farm through to December 1996, and from bioassay tests using extracts of these farmed prawns were positive by in situ hybridisation. This showed that the virus was present in prawn farms in northern Australia for at least 21 mo.

Tissues of prawns showing other viral or microbiological infections were tested for specificity with the gene probe. Monodon baculovirus, hepatopancreatic parvovirus, Australian infectious hypodermal and haematopoietic necrosis virus (AIHHNV) (Owens et al. 1992), and a Mycoplasma from prawns (Ghadersohi \& Owens 1998) failed to stain with the gene probe. However, all of these agents were probe-positive with their own respective gene probes, except AIHHNV, which was negative when tested with a probe derived from an isolate of IHHNV from Penaeus vannamei (DiagXotics Inc.). $P$. monodon experimentally infected with SMV (Fraser \& Owens 1996) was probe-positive in exactly the same pattern as prawns experimentally infected with extracts from MCMS prawns

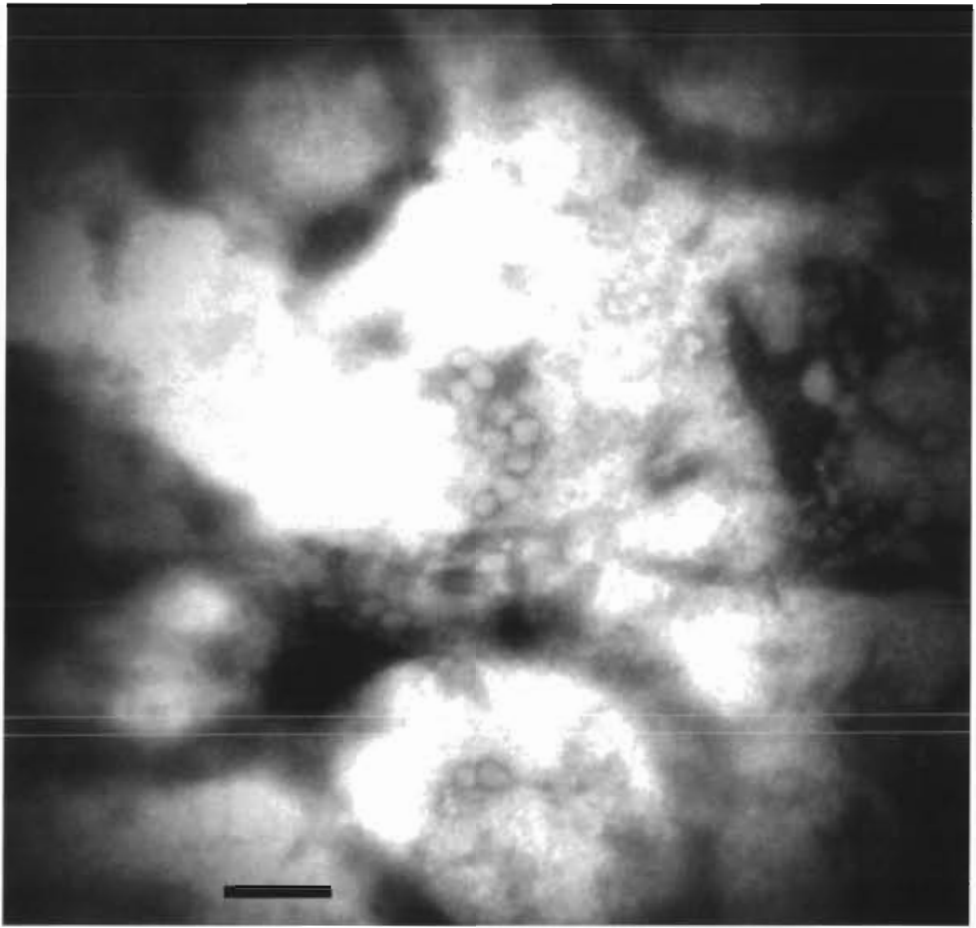

Fig. 1. A negatively stained, transmission electron micrograph of presumptive virions recovered from a $1.4 \mathrm{~g} \mathrm{~m}^{-1}$ band in a caesium chloride gradient of moribund MCMS prawn extract. Presumptive virions in the center of the photograph are spherical whilst some have straight sides and angular profiles characteristic of the genus Parvovirus (Murphy et al. 1995) (scale bar $=100 \mathrm{~nm}$ )

\section{DISCUSSION}

There is considerable evidence that one of the viruses associated with MCMS is a parvo-like virus. Parvoviruses have a buoyant density of 1.39 to $1.43 \mathrm{~g}$

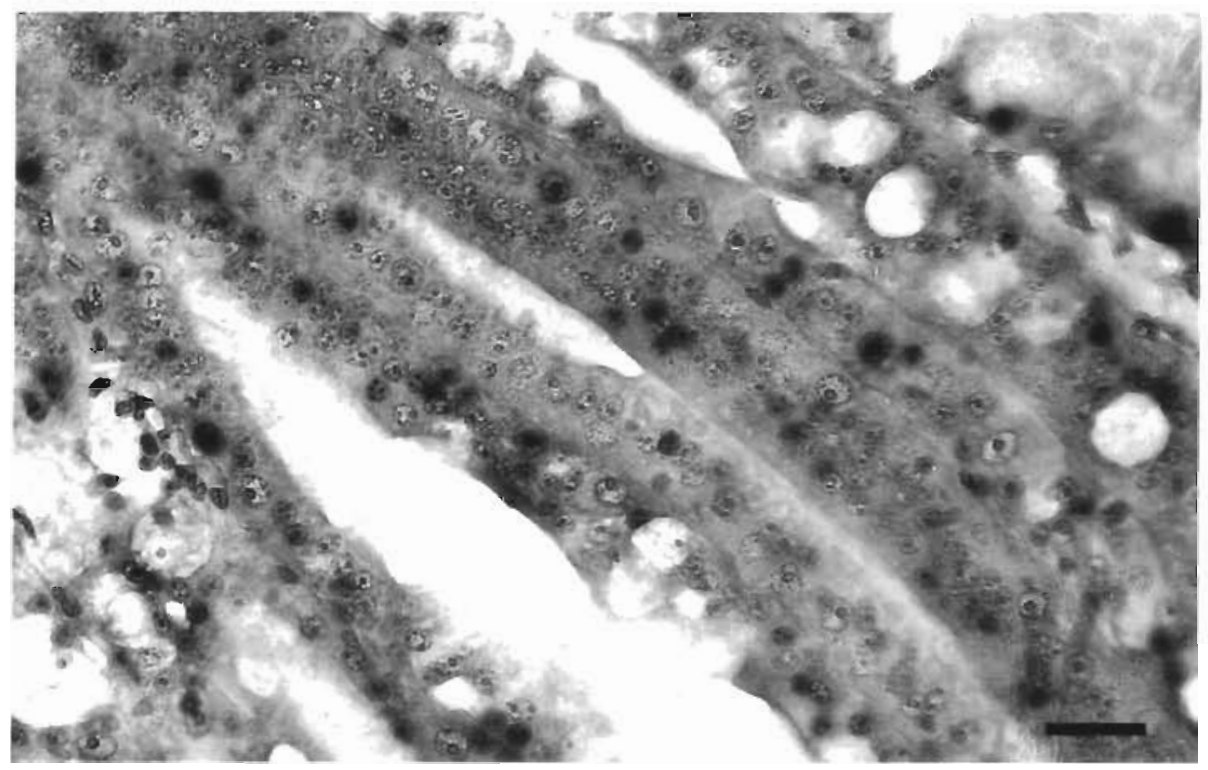

Fig. 2. Penaeus monodon. Photomicrograph of cells at the apical end of hepatopancreatic tubules of experimentally infected prawn showing scattered nuclei staining positive with the DIG-labeled gene probe $($ scale bar $=27 \mu \mathrm{m})$ 
Fig. 3. Penaeus monodon. Photomicrograph of the anterior midgut caecum from farmed MCMS prawn showing positive staining with the DIG-labeled gene probe. Note that in addition to the heaviest staining associated with nuclei that many nucleoli are also stained (scale bar $=36 \mu \mathrm{m}$ )

Fig. 4. Penaeus monodon. Photomicrographs of midgut cells from MCMS prawn tested with the DIG-labeled gene probe. (a) Farmed prawns showing probe-positive cells on the left ( $I=$ infected) and probe-negative cells ( $N=$ normal) on the right (scale bar $=$ $53 \mu \mathrm{m})$. (b) Experimentally infected prawns showing one lobe heavily stained, some lobes with scattered staining and cells beneath the basement membrane unstained. (Scale bar $=53 \mu \mathrm{m})$
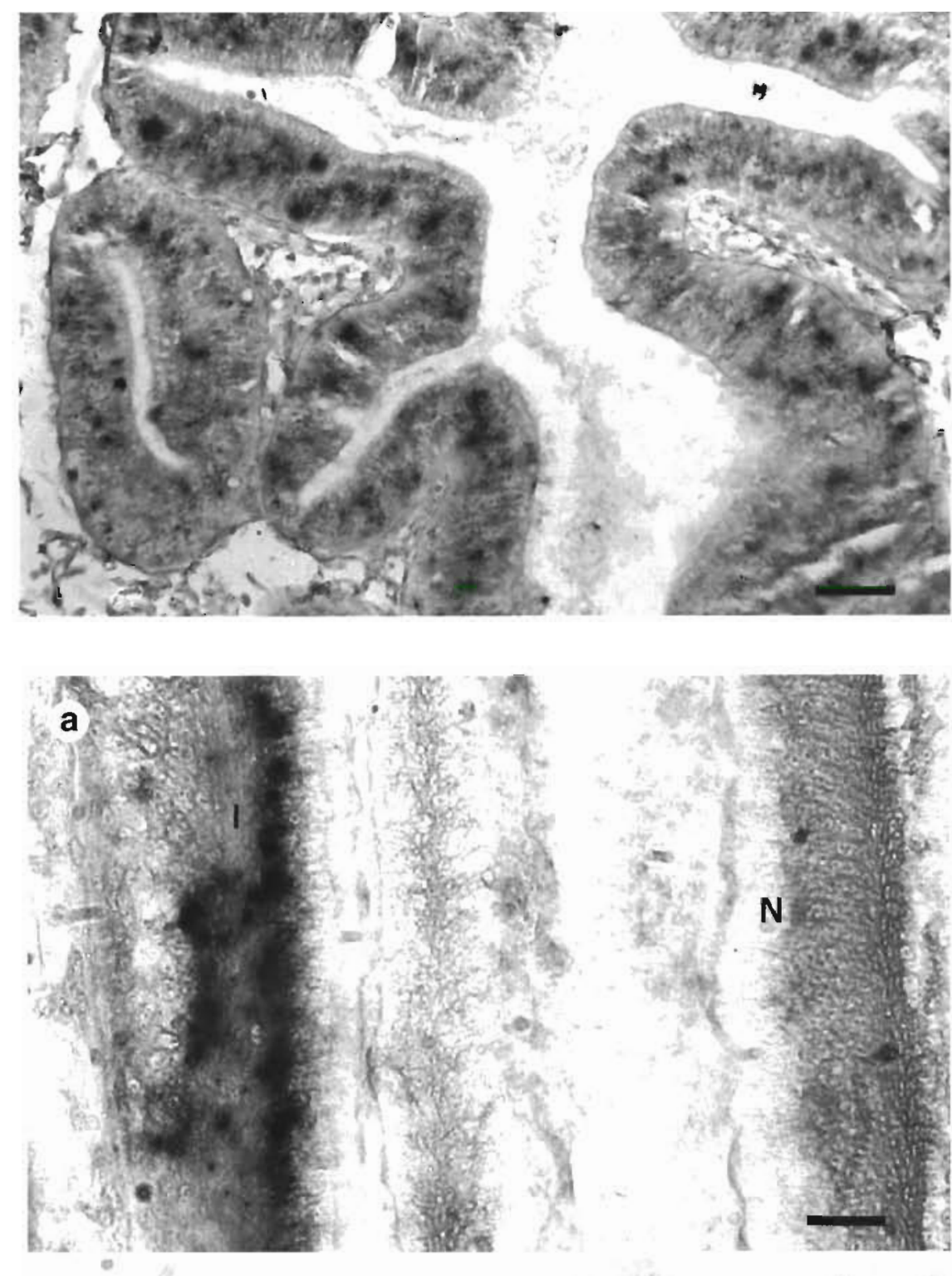

b

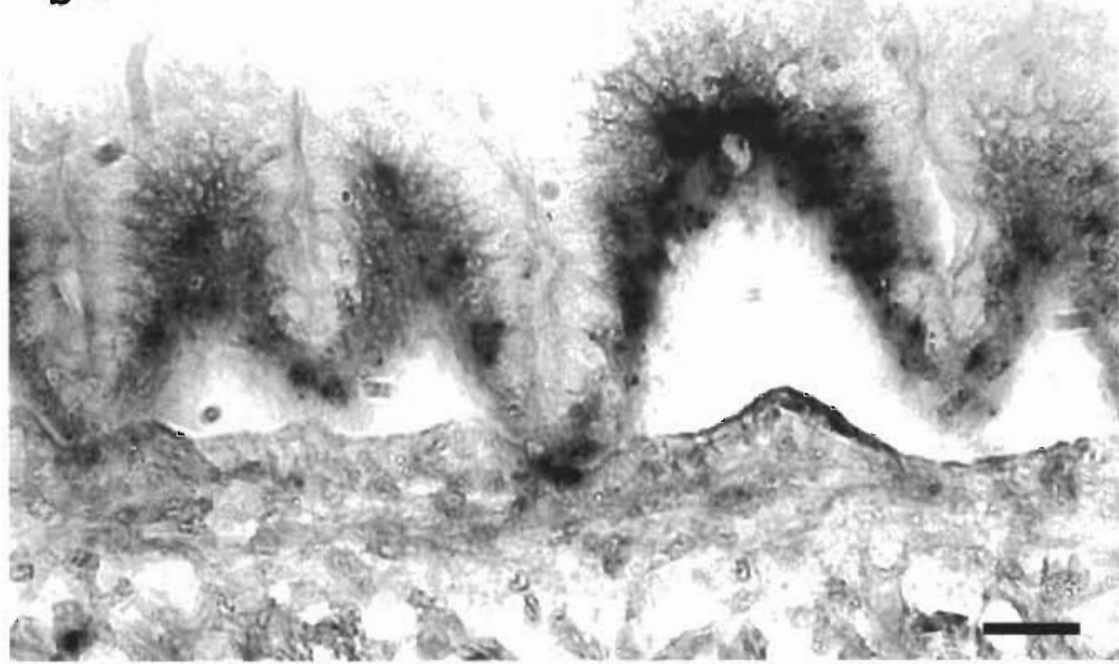



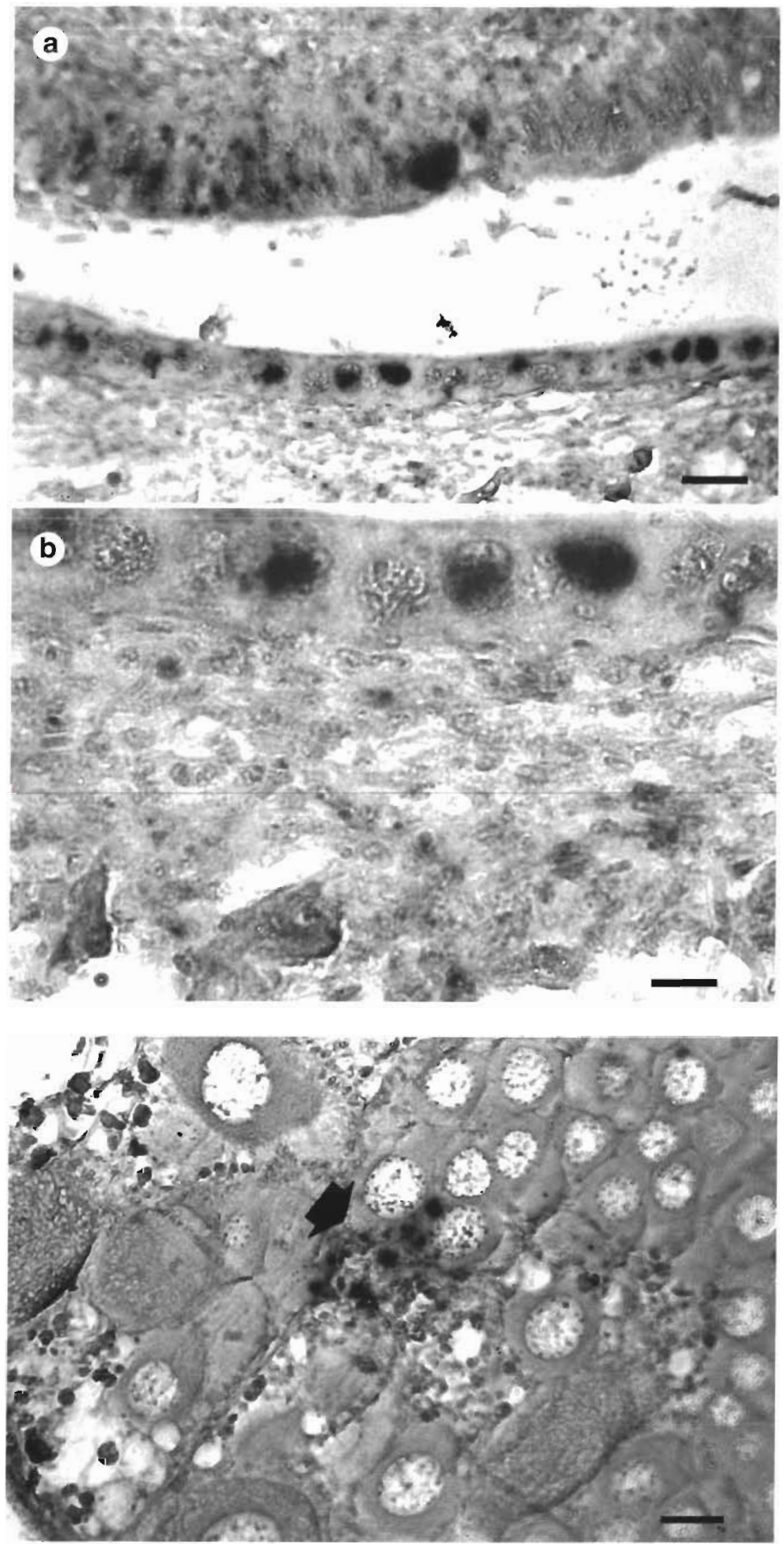

Fig. 5. Penaeus monodon. Photomicrograph of the terminal ampoule of the male reproductive tract from experimentally infected MCMS prawn tested with the DIG-labeled gene probe. (a) Low magnification of the tissue showing an intense positive intranuclear reaction (scale bar $=36 \mu \mathrm{m}$ ). (b) High magnification showing unstained, uninfected nuclei and intensely stained, infected nuclei in noncytolytic cells (scale bar $=$ $14 \mu \mathrm{m}$ )

Fig. 6. Photomicrograph showing focal, positive gene probe staining in the ovary of experimental MCMS prawn (scale bar

$$
=36 \mu \mathrm{m})
$$


Fig. 7. Photomicrograph showing limited gene probe staining (arrowheads) of both stromal cells and spheroids (S) in the lymphoid organ of experimental MCMS prawn $(\mathrm{N}=$ normal; scale bar $=14 \mu \mathrm{m}$ )

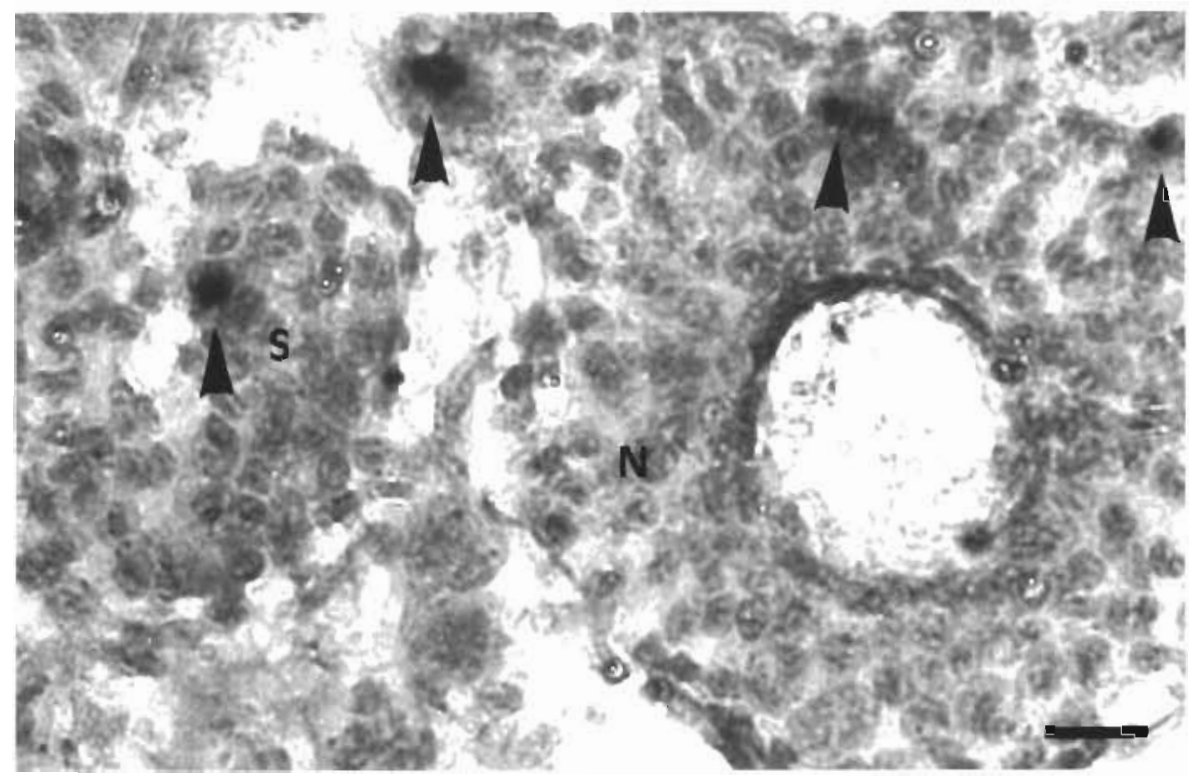

$\mathrm{ml}^{-1}$ (Murphy et al. 1995) whilst our sample came from a band at $1.4 \mathrm{~g} \mathrm{ml}^{-1}$. The size of the presumptive icosahedral virions visualised by TEM was 20 to $25 \mathrm{~nm}$, which is consistent with the size range of parvoviruses (18 to $26 \mathrm{~nm}$ ) (Murphy et al. 1995). Many parvoviruses cause enteritis in their hosts (e.g. human parvovirus, canine parvovirus and bovine parvovirus) and the gene probe here stained the enteric tissues of the prawn in natural infections. Parvoviruses can only replicate in actively dividing cells as they require cellular replication enzymes for virogenesis. Much of the staining in the prawns was associated with the zone of proliferation of the hepatopancreas (i.e. the outer edge of the organ). Likewise, midgut caecal cells (also with a very high mitotic index) gave strong probe-associated staining. Staining was mostly intranuclear and rarely cytoplasmic. Murphy et al. (1995) state that the progeny of infectious parvovirions accumulate in the cell nucleus. Cells showing a positive in situ hybridization reaction only in the nucleolus may have been at a non-proliferating stage of infection. Parvoviruses have an intimate association with the nucleolus and it is often changes in the nucleoli, including the separation of the fibrillar and granular portions, which are the first signs of infection, as in the genus Densovirus (family Parvoviridae) (e.g. Edgerton et al. 1997). In addition, the noncytolytic nature of the infections studied here is also characteristic of the genus Dependovirus (family Parvoviridae).

The relationships amongst the Australian parvo-like viruses of prawns needs clarification. Lymphoidal parvo-like virus (Owens et al. 1991) and Australian IHHNV (Owens et al. 1992) have been tentatively grouped together by Lightner (1996) due to their simultaneous occurrence in prawns dying of IHHNV. Hepatopancreatic parvovirus (HPV) as characterized by Lightner (1996) has never been found in the hepatopancreas of Australian juvenile Penaeus monodon either by the presence of pathognomic intranuclear inclusions or by extensive HPV-gene probe analysis. Animals that were gene-probe positive for SMV, were gene-probe negative for HPV (Kahn 1998). Hepatopancreatic strains of HPV do exist in Australian P. esculentus (Paynter et al. 1985), P. mer guiensis (Darmono 1987) and P. japonicus (Spann et al. 1997a), although their interrelationships are unknown. The most parsimonious conclusion for $P$. monodon is that SMV and the parvo-like virus described here for MCMS are either very closely related or identical. Apart from our positive probe results with the original SMV-infected prawns, this is further supported by the fact that the MCMSassociated virus appears to be enteric and to infect the midgut, the only place SMV virions were visualised using TEM (Fraser \& Owens 1996). In our opinion, the gene probe analysis data available at this time suggests that the various parvo-like viruses found in Australian penaeids are different. Further characterisation of these agents is required before definitive statements can be made as to whether the differences are at the strain or species level.

The aetiological agent(s) of MCMS still remains to be elucidated. The necessity of using mixed prawn homogenates which are then injected into farmed prawns possibly already harbouring a suite of viruses makes bioassays a crude investigative tool at best. The fact that the 1996 true controls died at rates equivalent 
to the test animals in 1995, 1996 and 1997 demonstrates this point. Which members of the viral cocktail were the most important is unknown and it may be that it is the mix itself that causes the mortality. Ethertreated prawn extract killed at a slower rate than untreated extract (15 or more additional days to mortality), suggesting that the parvovirus was capable of causing mortality but that its virulence was enhanced by the presence of other coinfecting viruses such as an enveloped, filiform virus (gill-associated virus, Spann et al. $1997 \mathrm{~b}$ ).

In our opinion, the epidemiological behaviour of this parvo-like virus lends some support to the viral accommodation hypothesis of Flegel \& Pasharawipas (1998). Their hypothesis proposes that prawns are capable of actively accommodating new viral infections by specifically suppressing viral-induced apoptosis, and that this capability can lead to a significant decline in the severity of epizootics from a new virus within 1.5 to $2 \mathrm{yr}$ of its first appearance in a population. However, according to their hypothesis, a consequence of the process for the shrimp industry is the occurrence of occasional batches of tolerant carrier prawns that are still vulnerable to massive mortality triggered by environmental or other stress which overrides the apoptosis supression mechanism. SMV produced epizootics with acute mortality in spawners in 1993 and 1994 (Fraser \& Owens 1996). Early descriptions of these mortalities uncannily described what might be interpreted as apoptosis of haemocytes in infected prawns (O'Neill 1994). During 1994, MCMS epizootics occurred on farms with prawns that were probe-positive for this virus. By 1995, when researchers became involved, the virus/prawn relationship had apparently changed, such that probe studies showed the presence of the viral genome in the surprising absence of cytolysis (i.e. absence of apoptosis?). Furthermore, farmers in 1996/1997 described environmental factors (e.g. low oxygen stress, rapid salinity change) as being the reasons for mortalities in ponds where we found strongly probe-positive shrimp. A similar scenario occurred in Thailand with yellow-head virus disease (Pasharawipas et al. 1997) and led to the formulation of the viral accommodation hypothesis (Flegel \& Pasharawipas 1998).

Acknowledgements. This research was funded by contributions in decreasing order by James Cook University, Queensland Department of Primary Industres Oonoonba Veterinary Laboratories; Fisheries Research Development Corporation and CSIRO Division of Fisheries, Cleveland. Dr Paul Muir supplied cell-free filtrate from prawn farms for 3 bioassays in 1995. The prawn farmers of northern Queensland are thanked for access to their farms, their records and their support.

\section{LITERATURE CITED}

Altschul SF, Gish W, Miller W, Myers EW (1990) Basic alignment search tool. J Mol Biol 21b:403-410

Bell TA, Lightner DV (1988) A handbook of normal penaeid shrimp histology. World Aquaculture Society, Baton Rouge

Bonami JR, Trumper B, Mari J, Brehelin M, Lightner DV (1990) Purfication and characterisation of the infectious hypodermal and haematopoietic necrosis virus of penaeid shrimps. J Gen Virol 71:2657-2664

Culling CFA, Allison RT, Barr WT (1985) Cellular pathology techniques, 4 th edn. Butterworths, London

Darmono (1987) Studies on the pathology of cadmium and nickel toxicity in the banana prawn (Penaeus merguiensis de Man 1888). MSc thesis, James Cook University of North Queensland

Durand S, Lightner DV, Nunan LM, Redman RM, Mari J, Bonami J (1996) Application of gene probes as diagnostic tools for white spot baculovirus (WSBV) of penaeid shrimp. Dis Aquat Org 27:59-66

Edgerton B, Webb R, Wingfield M (1997) A systemic parvolike virus in the freshwater crayfish Cherax destructor. Dis Aquat Org 29:73-78

Flegel TW, Pasharawipas T (1998) Viral accommodation: a new concept for crustacean response to viral pathogens. In: Flegel TW (ed) Advances in shrimp biotechnology. National Center for Genetic Engineering and Biotechnology, Bangkok (in press)

Fraser CA, Owens L (1996) Spawner-isolated mortality virus from Australian Penaeus monodon. Dis Aquat Org 27: $141-148$

Ghadersohi A, Owens L (1998) Isolation of Mycoplasma spp from moribund Australian prawns (Penaeus monodon) and development of a polymerase chain reaction for detection of prawns Mycoplasma spp. Dis Aquat Org (in press)

Kahn S (1998) The role and significance of hepatopancreatic parvovirus in penaeid prawns in northern Queensland evaluated by in situ hybridisation. MSc thesis, James Cook University

Lightner DV (1996) A handbook of pathology \& diagnostic procedures for diseases of penaeid shrimp. The World Aquaculture Society, Baton Rouge

Murphy FA, Fauquet CM, Bishop DHL, Ghabrial SA, Jarvis AW, Martelli GP, Mayo MA, Summer MD (1995) Virus taxonomy. Sixth Report of the International Committee on Taxonomy of Viruses. Springer-Verlag, Vienna

O'Neill AC (1994) Flow cytometry: a potential tool for assessing the health of the tiger prawn, Penaeus monodon. Honours thesis, James Cook University of North Queensland

O'Shade R, Blundell MC, Cotmore SF, Tattersall P, Astell CR (1986) Nuecleotide sequence and genome organisation of human parvovirus B1.9 isolated from the serum of a child during aplastic crisis. J Virol 58:921-936

Owens L, de Beer S, Smith JR (1991) Lymphoidal parvo-like virus from Australian penaeid prawns. Dis Aquat Org 11: $129-134$

Owens L, Anderson IG, Kenway M, Trott L, Benzie JAH (1992) Infectious hypodermal and haematopoietic necrosis virus (IHHNV) in an interspecies hybrid penaeid prawn from tropical Australia. Dis Aquat Org 14:219-278

Pasharawipas I, Flegel TW, Sriurairatana S, Morrison DJ (1997) Latent yellow-head infections in Penaeus monodon and implications regarding disease tolerance or resistance. In: Flegel TW, Menasveta P, Paisarnrat S (eds) Shrimp biotechnology in Thailand. National Center for Genetic 
Engineering and Biotechnology, Bangkok, p 45-53

Paynter JL, Lightner DV, Lester RJG (1985) Prawn virus from juvenile Penaeus esculentus. In: Rothlisberg PC. Hill BJ, Staples DJ (eds) Second Aust Natl Prawn Sem. NPS2, Cleveland, Australia, p 61-64

Rolighed J, Lindeberg H (1996) Detection of HPV 11 DNA in paraffin embedded laryngeal tissure with a DIG-labclled DNA probe. Non-radioctive in situ hybridization application manual, 2nd edn. Boehringer Mannheim, Mannheim, p $122-125$

Editorial responsibility: Timothy Flegel, Bangkok, Thailand
Sambrook J, Fritsch EF, Maniatis T (1989) Molecular cloning. A laboratory manual. Cold Spring Harbor Laboratory, Cold Spring Harbor, New York

Spann KM, Adlard RD. Hudson DA, Pyecroft SB, Jones TC, Voigt MOC (1997a) Hepatopancreatic parvo-like virus (HPV) of Penaeus japonicus cultured in Australia. Dis Aquat Org 31:239-241

Spann KM, Cowley JA, Walker PJ, Lester RJG (1997b) A yellow-head like virus from Penaeus monodon cultured in Australia. Dis Aquat Org 31:169-179

Submitted: January 12, 1998; Accepted: July 29, 1998 Proofs received from author(s): November 19, 1998 